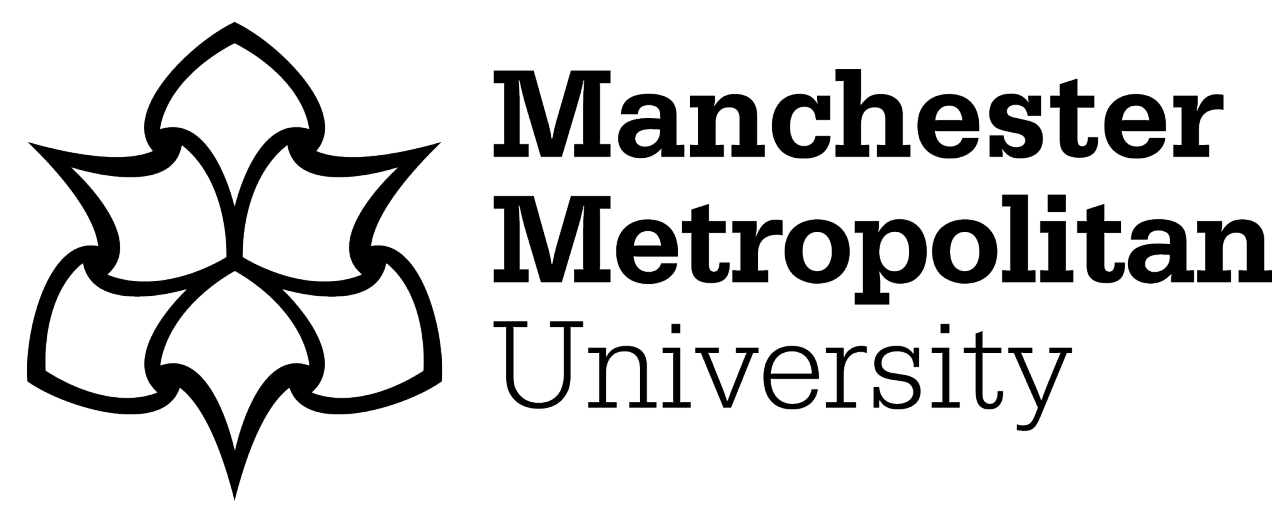

Ahmed, A ORCID logoORCID: https://orcid.org/0000-0002-6164-0656 and Rogers, M (2016) Polly's story: Using structural narrative analysis to understand a trans migration journey. Qualitative Social Work, 16 (2). pp. 224-239. ISSN 1473-3250

Downloaded from: https://e-space.mmu.ac.uk/625889/

Version: Accepted Version

Publisher: Sage

DOI: https://doi.org/10.1177/1473325016664573

Please cite the published version 


\title{
Polly's story: Using structural narrative analysis to understand a trans migration journey
}

\author{
Anya Ahmed and Michaela Rogers \\ University of Salford, UK
}

\begin{abstract}
There is scant theoretical and empirical research on experiences of trans ${ }^{\prime}$ and its significance for social work practice. In this paper, we premise that research on trans identity and practice needs to be located in particular temporal, cultural, spatial/geographical contexts and argue that a structural narrative analytical approach centring on plot, offers the opportunity to unravel the 'how' and 'why' stories are told. We posit that attending to narrative structure facilitates a deeper understanding of trans people's situated, lived experiences than thematic narrative analysis alone, since people organise their narratives according to a culturally available repertoire including plots. The paper focuses on the life and narrative of Polly, a male-to-female trans woman, and her gender migration journey using the plot typology 'the Quest'. We are cognisant of the limitations to structural narrative analysis and Western conventions of storytelling, and acknowledge that our approach is subjective; however, we argue that knowledge itself is contextual and perspective ridden, shaped by researchers and participants. Our position holds that narratives are not - and cannot - be separated from the context in which they are told, and importantly the resources used to tell them, and that analysing narrative structure can contextualise individual unique biographies and give voice to less heard communities.
\end{abstract}

\section{Keywords}

Structural narrative analysis, plot, trans identity, biographical work

\section{Introduction}

There is limited theoretical and empirical research on experiences of trans and its importance for social work practice. Arguably, research on trans subjectivity

\section{Corresponding author:}

Anya Ahmed, University of Salford, C504 Allerton Building, Frederick Road, Salford M6 6PU, UK.

Email: a.ahmed@salford.ac.uk 
should be underpinned by an understanding of trans identity and practice, and located within wider social contexts (Rogers, 2013). In this paper, we propose that a narrative approach is integral to understanding trans identity within the context of social work practice, since social work itself is undergirded by an 'essentially narrative nature' (Baldwin, 2013: 133). We argue that a structural narrative analytical approach offers the opportunity to unravel 'how' and 'why' stories are told and facilitates a deeper understanding of (trans) people's situated, lived experiences than thematic analysis alone (Ahmed, 2013, 2015). Interpreting narrative in this way helps social work move towards inclusivity and away from oppressive modes of practice which perpetuate hierarchies of knowledge and reproduce dominant and normative forms of cultural representation.

We introduce the reader to Polly, a male-to-female trans woman, and present a structural narrative analysis of her story centring on the use of plot, to gain knowledge of her unique biography in particular temporal, cultural, spatial/geographical contexts. We are mindful that there are limitations to structural narrative analysis; for example, Denzin (1989) refers to a crisis of representation and legitimation (see also Ahmed, 2013); and Minh-Ha (1989) criticises structural approaches on the basis that Western conventions of storytelling are privileged and analysis becomes more focused on the intellect of the researcher, than on the lives of the 'researched'. We acknowledge that our approach is subjective and argue that knowledge itself is contextual and perspective ridden, shaped by researchers and participants. We also premise that narratives do not speak for themselves: they need to be analysed and interpreted (Ahmed, 2013, 2015; Riessman, 1993, 2008; Temple, 2008). Our position, therefore, holds that narratives are not - and cannot be separated from the context (the 'where' and the 'when') in which they are told, and importantly the resources used to tell them (the 'how'). Significantly, people's narratives are taken from a culturally available repertoire including plots (Ahmed, 2013, 2015). It is also important to examine the purpose of the narrative (the 'why') and we do this in relation to 'the end point of plot movement' (Bakhtin, 1981: 89).

The paper is organised as follows: first, we introduce Polly; second, we discuss our approach to structural narrative analysis and present our analytical use of narrative plot; third, we provide an analysis of Polly's narrative using the 'quest' plot typology in order to illuminate her 'migrating story' (Ekins and King, 2006); and fourth, we consider the usefulness of plot-centred narrative analysis for understanding trans experiences and social work practice. Our central premise is that narrative benefits social work practice since, as a 'Method, perspective, process and product... narrative asks new questions of, and casts new light on, not only how social work is done ... but also on the narrative environments in which social work is practised' (Baldwin, 2013: 4). For example, as a process in social work contexts, narrative offers therapeutic possibilities by enabling individuals to make sense of significant lived experiences. Understanding past experiences can help people identify strengths and enable them to draw on previous coping strategies. In this way, narrative practice helps people reframe traumatic and harmful life events and move towards positive change. 


\section{Introducing Polly}

During 2012, Polly took part in a UK study which explored trans people's experiences and perspectives on domestic violence and abuse (DVA). Fifteen trans-identified participants were interviewed along with nine practitioners who worked across the DVA sector in various professional roles. In the original study, narrative analysis was conducted following the principles of Doucet and Mauthner's (2008) 'Listening Guide'. For the analysis here, Polly's story has been chosen as it provides an example of how trans identity can shape lived experience in childhood and adulthood with some aspects of the narrative typifying many of the experiences recounted by participants in the original study.

\section{An interpretive approach to structural narrative analysis}

Our epistemological approach to narrative analysis focuses on the significance and influence of context; knowledge, therefore, can be understood to be temporally, culturally and spatially specific (see Ahmed, 2013, 2015; Burr, 1995; Gergen, 1999). It follows then that what is thought to be, or constructed as 'true', is shaped by the particular contexts in which it occurs, and phenomena have different meanings depending on when and where they occur (Gergen, 1999: 14). In this way, we present Polly's narrative as a construction of her unique biography: a subjective account, influenced by context and also as reconstructing context.

Originally used in literary analysis (Riessman, 2008), the study of narratives now crosses a number of disciplines and encompasses a range of theoretical and methodological approaches (Stanley and Temple, 2008). There is no agreement on what narrative is or how they should be analysed (Ahmed 2013, 2015; Riessman, 1993, 2008), and there are many different kinds of structural narrative inquiry. For the purpose of our analysis, we define narrative as recorded, transcribed stories, which are constructed into units for interpretation (Ahmed, 2013, 2015; Riessman, 2000, 2003). We see narrative research as related to the situated study of individuals and their lives (Ahmed, 2015). Narrating can also be understood as a mechanism through which people examine their lives and gain understanding of the contexts in which they live (see Ahmed, 2015; Polkinghorne, 1988; Ricouer, 1984). This has particular resonance for social work practice which is person-centred, transformative and holistic, rather than that which is primarily concerned with managing risk (Featherstone et al., 2014). Some approaches treat narratives as objective and limited to content and themes, whereas our interpretive view of narratives is that they are not 'ethnographic testimonials' (Ahmed, 2013, 2015); and for us, it is epistemologically congruent to refer to narrative understanding rather than truth (Ricouer, 1984). Analysing a single narrative has theoretical value: although we are all uniquely positioned in time and space and our experiences are particular to us, 'embedded in our uniqueness are common threads which connect us all' (Day Sclater, 1998: 67). Polly's subjective truths are of wider relevance and allow us to generalise to other transgender experiences, since she 'draws on wider 
intertextual discourses which shape and constrain the meanings she is able to construct' (Edwards and Potter, 1992 cited in Day Sclater, 1998: 75).

\section{Analysing Polly's narrative: The usefulness of plot}

Narrative can be understood as a 'production' (Ricouer 1984, 1985 and 1988, drawing on Aristotle's Poetics (c335 BC)). Aristotle regarded narrative as the memesis - or imitation - of lived experience. Plot (or 'muthos' for Aristotle) is not seen as a static structure but the work of composition. There are wide differences in what is analysed in terms of structure; ${ }^{2}$ here, we analytically bracket (Ahmed, 2013, 2015; Gubrium and Holstein, 1998) to focus on plot. We see the plot of a narrative as how events are coherently brought together (Czarniawska, 2004), the way narrators organise events and experiences (Riessman, 1993, 2008), and also how narrative analysts ultimately impose structure (Ahmed, 2013, 2015). Examining plot can be understood as a whole content approach to narrative analysis (see Lieblich, Tuval-Mashiach and Zilber; cited in Josselson, 2007 and Ahmed, 2013). In any narrative, there are multiple, separate incidents and these incidents can be understood as forming the 'whole story'. People can be understood to organise their experiences when they tell stories, thus creating a 'whole story' from multiple events (Ahmed, 2015; Ricouer, 1984). Again, and importantly, plots are situated in, and drawn from social, cultural, spatial and temporal contexts (Ahmed, 2013, 2015).

The concept of 'narrative linkage' (Gubrium and Holstein, 2009) is also useful when focusing on plot in terms of how storytellers organise multiple incidents into a meaningful whole (Ahmed, 2013, 2015). Narrative linkage is provided by the narrator when they 'step outside' the narrative to contextualise the plot (Ahmed, 2015). It is difficult to examine structure without also analysing content, and we are mindful that out interpretations should always be embedded in the larger intertextual arenas in which they are located (Denzin, 1989). This combined approach illuminates the link between meaning and action, which is helpful when looking at how Polly makes sense of her lived experiences of being transgender. Plot also represents a chronological - or temporal - organisation of events (Ahmed, 2013, 2015), and chronological events are made meaningful by relating one to another through this 'temporal dialectic' (Ricouer, 1984, 1985, 1988).

To analyse Polly's narrative, we use the 'quest' plot typology, taken from Christopher Booker's (2004) assimilation of 'Seven Basic Plots' from literature, film, the Bible, ancient myths and folk tales. He classifies the seven plots as: overcoming the monster; rags to riches, the quest, voyage and return; comedy; tragedy; and rebirth. Below we explain how and why we use the 'quest' typology to illuminate Polly's migrating story (Ekins and King, 2006). The aim of the Quest is the life-renewing goal (Booker, 2004), usually represented by a new home in a 'better' place. There are five stages to the Quest, beginning with ('The Call') ${ }^{3}$ when the central character feels compelled to leave an 'atmosphere of ... constriction' (Booker, 2004: 71). The second stage is ('The Journey'), which involves a 'series of 
life-threatening ordeals (Booker, 2004: 83) including 'monsters' and obstacles to overcome and temptations to be resisted. The third stage, ('Arrival and Frustration'), is when the central character almost reaches the goal, but is faced with a set of further obstacles; the fourth stage, ('The Final Ordeals'), denotes a last series of 'tests' which the hero must endure before reaching the goal. ${ }^{4}$ The fifth stage is ('The Goal'), where the central character at last finds 'the life-transforming treasure $^{5,}$ (Booker, 2004: 83). The possibilities offered by plot analysis for social work include the opportunity to acknowledge times when the individual (Polly) has experienced and overcome adversity but, more importantly, it helps to identify and promote the social relationships, personal qualities or strengths which have enabled that person to overcome adversity and grow (Saleebey, 2013).

The Quest plot typology illuminates Polly's situated experiences of being transgender, since: 'The theme of undergoing a perilous journey is a common one in transsexual autobiographies' (Ekins and King, 2006: 44). ${ }^{6}$ Polly's interview began with the researcher asking a 'grand tour question' (Spradley, 1979): 'Can we can start with you talking about your experience of being transgender?' In Quest stories, often the central character is accompanied by 'companions' on the journey. However, Polly's narrative does not "include" such characters - she presents herself as being on the journey alone, but there are 'others' whom she encounters along the way; her parents and sister; her wives, partners and boyfriend; her daughters and stepdaughters; service providers (social workers and medical staff); 'unknown' others, for example the people who were responsible for assaulting her, and 'known others', friends who appear in the last part of her narrative. We analyse Polly's narrative in relation to the stages identified above, acknowledging that the purpose of her narrative (the 'why'), apparent in the end point of plot movement (Bakhtin, 1981), is self-acceptance, and this frames and shapes the telling (the 'how').

\section{The Quest's beginning: 'The call'}

In the first part of her narrative, Polly conveyed an awareness of transgressing accepted cultural norms: the child Polly was aware of the cisgendered ${ }^{7}$ expectations of what it was to 'be' a boy. Although Polly's five-year-old self could not properly conceptualise or articulate what was 'wrong', she knew something was amiss by her use of 'you realise quite early that you're different, not the same'. The call for Polly was precipitated by strong feelings of not relating to her assigned gender. She admired her sister, wanted to 'be like' her, but was consumed by guilt for feeling this way:

I think like most people you realise quite early that you're different, not the same, sort of different. To me when I was about five - [I think you'll find that's a fairly general age] - I had a sister she was just over a year older than me, as I grew up I used to really look at her and admire [her] and think 'Oooh I'd love to be like you'. You know... and wear the things she wore, and stuff like that. And then those 
thoughts go out of your mind because you think you're wrong. You get this guilt, this real guilt complex.

Feelings of guilt endured throughout Polly's migration journey. Indicated in parentheses, Polly stepped outside of her narrative to provide narrative linkage (Gubrium and Holstein, 2009) from the temporal vantage of the present: from her experience and knowledge of trans, early childhood is often when people become aware that they do not 'fit' in the gender into which they were born. An important message is contained in Polly's narrative in terms of social work with children and adults who feel that they do not 'fit' into normative social categories, as well as the need to be mindful that they are agentic beings with thoughts and feelings that should be heard and validated. Polly's 'vocabulary of motive' (Ekins and King, 2006; Mills, 1940) centred on her realisation of being 'different'. Ekins and King (2006) cite Castles and Miller's (1998) often quoted 'age of migration' to refer to global mobility and flux, and posit that 'We are also in the age of Gender Migration' (2006: 43). Migration can also be understood as a 'quest' (Ahmed, 2013, 2015; Benson, 2011) for a better - or different - life. In this way, gender changing can be understood as migrating across borders, or social 'locations', and this conceptualisation is useful in how we approach Polly's narrative. Often, transgender migrants feel 'out of place' before they migrate (Ekins and King, 2006), and although the call for Polly was strong, guilt displaced her 'true feelings': 'Even so [she] may face every kind of discouragement and opposition before [she] can depart' (Booker, 2004: 71).

\section{The journey}

The journey is precipitated by the call and Polly's journey across dangerous 'wild, alien and unfriendly' terrain' (Booker, 2004: 73) encompassed a number of stages. The first stage included her childhood, adolescence and young adulthood, characterised by both self-knowledge and concealment. From the age of six or seven, Polly was in conflict, aware of her feminine self, but simultaneously aware that she transgressed cisgender norms. In the early stages of her journey, Polly's survival strategy was to adopt an outwardly masculine persona, fulfilling expected gender norms in the choices she made:

The more you think about ... the more you think you're feminine, the more you react against it ... The more rough and tumble you tend to do. As I grew up I was interested in, I wanted to do sewing. I wanted to play with dolls' houses but I was told that wasn't on, so I had Meccano ${ }^{8}$ instead. Built houses [laughs]. Then you carry on with this.

For Polly, the wild and unfriendly terrain in this part of her journey denoted the wider cultural and temporal context in which she was located, one which did not sanction her expressions of femininity. Instead, she was forced to conform to social 
norms, and play with Meccano, as a boy would be expected to. Her rueful laugh and use of 'built houses' (instead of playing with dolls' houses) suggests resigned conformity at this stage in her life.

In the following excerpt, Polly talked about the first time she 'dressed up' in her sister's clothes. Although she enjoyed the experience and thought it was 'nice', she was also desperately afraid of being discovered:

I think the first time I dressed up... was it a tutu or something... of my sisters...? Yeah, a ballerina thing... and I thought 'Oh that's nice'. But then I heard somebody coming home and I couldn't get it off quick enough, you know. But it couldn't come off and I was panicking. I managed to get it off and no-one was any the wiser.

Covertly dressing as female and outwardly presenting as male became a pattern throughout Polly's life. In her narrative, dressing as female was constructed as being Polly's 'true identity', the 'self' she was most comfortable with, but fear of discovery and being negatively judged prevented her from revealing this self just yet, since she was aware that it was widely perceived as transgressive in some profound way.

\section{Overcoming monsters}

As highlighted above, the quest is characterised by danger, and the 'hero' or central character must overcome obstacles and 'monsters' in order to fulfil the quest's goal of a home in a new location. Nordmarken's (2014) autoethnographic account is useful in relation to the 'profound symbolic significance' (Booker, 2004: 22) of the 'monster' for trans experiences. Drawing on Mary Shelley's monster in Frankenstein, and Susan Stryker's use of 'monstrosity' as a tool of resistance and reconnection across difference in gender migration, Nordmarken describes his experiences of transitioning from female-to-male, using the term 'monster' in relation to being made monstrous by the marginalising action of 'Others' (Nordmarken, 2014: 38). From an early age, Polly was aware of the risk of 'being monstered' by others, but she also internalised this, seeing 'the problem' as residing in and with her. The early part of Polly's journey was characterised by conflict, by internal wrangles to suppress her 'true identity':

You fight against it and ... I did quite successfully, looking back ... You do, you really fight against it. But you don't really know why you're fighting against it, but you know you're going to upset people if you told them this is what you want.

Polly lived a 'double life' in her childhood, outwardly conforming to wider cultural and social gender norms of the time, playing with her train track and Meccano, but enjoying a 'thrilling escape' (Booker, 2004) whenever she had the opportunity to 
dress as Polly. On these occasions, Polly would regularly almost allow herself to be discovered:

So I had my train track and my Meccano but if they were out I'd be dressed as Polly and I'd really enjoy it. I'd leave it until the last second, as the car came in the drive, I'd be taking things off. I don't know if it was the adrenalin rush or what it was I wanted to be Polly as long as I could.

The compulsion to 'cross dress' featured throughout Polly's childhood into adolescence and she found further opportunities to do so when her sister went away to boarding school and her parents were out. She presented this as a guilty secret, and as a 'temptation' to overcome; the guilt then had to be expunged:

And then sometimes I'd wear my mum's lipstick - which took a lot of getting off. Oh ... but I was at my happiest when I was like that ... then I'd get this guilt complex. I'd go out gardening then as we had this great big garden. Then of course there would be a bonfire and I burnt those clothes on the bonfire, get rid, get rid of the guilt. Yeah, burn the guilt, get rid of them all. Until the next [time]... and this went on. I loved doing it.

\section{Constriction and release}

The second stage of Polly's journey began in the 1960s when she was in her early 20s: at this time, when 'there was no help', as 'Paul', she decided to get married to 'cure' herself. Cure usually refers to medical intervention or correction of something that is 'wrong' and reflects public narratives and understandings of transgender at this time (Ekins and King, 2006):

There was no help around at the time and I grew up and I thought marriage will cure, that's the thing.

However, this did not work and Polly again found that she could not suppress the desire to express her female identity. In the Quest, the journey is characterised by 'Alternating periods of life-threatening constriction followed by life-giving release' (Booker, 2004: 73). Polly suppressed her 'true self' for periods of time but found that she could not do so indefinitely. Polly spent the marriage in deep conflict, unable to resist the 'temptation' of wearing feminine clothing, yet outwardly displayed exaggerated masculinity:

I progressed from working on the motorway, driving trucks, drinking a lot, being a real male person, but wearing knickers at the same time, but no-one knew that. It was my little secret. 
The pattern of concealment, Polly's 'little secret', 'dressing up' in private and presenting as she was normatively expected to, continued into her adult life. Polly adopted and practised a 'macho persona' as a distraction, eventually turning more to alcohol when she realised that the marriage and having a daughter had not in fact 'cured' her:

I was married, had a child, a girl and then I thought would cure it but these things came more and more and I think that's why I came to drink, drinking more and smoking up to 80 cigarettes a day.

Polly perhaps felt even more pressure to perform as 'male' once married. As the marriage came to an end Polly was in turmoil, isolated and lost:

I couldn't be more macho ... but I'd still got this issue that this wasn't the person that I wanted to be. No matter what I did. I got divorced, was still drinking... I was all over the place. No idea where to go for help. No idea why I needed help. I didn't know if I needed help.

\section{Guilt and despair}

The third part of Polly's journey followed the end of her first marriage. This period was characterised by extremely heavy drinking and a new form of despair; Polly only felt 'sober' when 'drunk':

I was that sozzled I was only sober when I was drunk ... I couldn't cope unless I had got drink inside me, a bottle of scotch a day.

Alcohol helped Polly 'cope', and enabled her to suppress her 'guilt complex'. Eventually Polly gave up alcohol, remarried and had another daughter. By this time she had lost her house, business and was living in a mobile home, and was eventually rehoused by the local authority. Polly began 'dressing up' again, this time with her wife's knowledge; however, her 'secret' was used against her when they eventually divorced and Polly was again made vulnerable:

My wife at the time she did know and she was OK, but then she completely turned it against me when the divorce came up, [said] I'd insisted and stuff like that.

\section{Taking control}

The fourth and final stage of Polly's journey involved her meeting a new partner and being open about 'cross-dressing'. The risk of being 'monstered' 
by others was always an obstacle to negotiate; however, at first, her partner seemed to accept this:

I met a lady there and seemed to hit it off alright... I met her a couple of times and one time [I must admit, I did have a drink before that night]. I said to her 'I've got something to tell you' and her reaction was 'Well yeah as long as you don't wear any of my stuff because you're a lot bigger than me'.

Again, Polly stepped outside of her narrative to provide linkage (Gubrium and Holstein, 2009) to the context, indicating that before she could disclose her 'secret' she needed to consume some alcohol, although by this time she had stopped drinking. However, over time Polly's confidence grew until she finally told her partner that she believed herself to be transgender, but her partner was unable to accept it:

Then I said 'I'm fairly convinced I'm transgender'. She didn't have any control of me then. This was me talking... So things became a bit fractious.

The journey stage for Polly was now over, but 'The journey in the Quest only makes up half the story' (Booker, 2004: 79). Living as - or 'being' Polly - did not denote the end of the quest. There were two further stages where Polly began to be reconciled to the acceptance and non-acceptance of others, before she reached her goal and the final stage of self-acceptance: 'Arrival and Frustration', and the 'Final Ordeals'.

\section{Arrival and frustration}

Now living openly as Polly, in a new place, the life renewing 'goal' was in sight. However, before the goal can be secured, 'A new and terrible series of obstacles' (Booker, 2004: 83) must be overcome. Polly no longer had to keep her 'guilty secret', but she was in poor mental and physical health and was vulnerable to the reactions of others, experiencing a series of attacks, acts of vandalism and burglaries, suspecting that her ex-partner and stepdaughter were involved in some way:

I had my car... [vandalised] with glass put under the wheels and an arson attack, petrol through the letter box... I ended up with three cars kicked in, windows broken in the house. I ended up with broken ribs when I took the dogs for a walk one evening, two local yobs jumped out from behind a tree and gave me a good seeing to. Next door would come over and have a go at me, take my hair off me, take photographs of me without my wig, with no hair on. Even the police in the end said they couldn't do that much.

Although Polly no longer hid her 'true self', now presenting as female, she was exposed and unprotected and had to deal with the negative attitudes of others. 
Clearly, at this point of Polly's story she was vulnerable. The temporal, cultural and geographical context was significant in terms of the level of Polly's vulnerability; she resided in a small village at a time when trans people were rarely visible in public life. In social work practice, these biographical details can considerably enhance and inform assessments, planning and interventions as a focus on the confluence of particular narrative forms (of vulnerability and abuse, for example) with change and growth helps to identify resilience and, importantly, forms of coping (Saleebey, 2013).

\section{Final ordeals}

By now Polly had moved to the North West of England, finding the anonymity and acceptance she craved:

No-one took any notice of me. No-one bothered. I went out and about. It's a different world up here. No-one gives a monkey's.

However, there were several final ordeals that Polly had to overcome before reaching the quest's goal. First, she needed to come to terms with being estranged from her daughters:

They just don't want to know me. I did try and contact my youngest daughter when I was in the village in North Wales... and then it just turned completely sour... My eldest daughter told me to sod off years ago. That was before the gender issue came in.

Polly's anguish regarding the lack of contact with her daughters was countered somewhat by her recalling her recent 70th birthday gathering and how people from different parts of her life came together to celebrate. This conveys a strong sense of affirmation, but appreciating those who accepted and knew her in the present precipitated a reflection on a past time when Polly did not feel accepted. In the following excerpt, Polly talked about her experiences of social work and health professionals who she felt had marginalised and disempowered her:

As far as social work is [concerned]... when I was in North Wales I had a social worker ... but they didn't understand the gender side of it whatsoever.

One day a varicose vein burst on my leg... whilst I was in the shower... I held my towel on it, rang the doctor, they rang the ambulance... the ambulance men came in and I wouldn't go ... Because I hadn't got my wig on and he wouldn't put it on for me. Said it wasn't his job. Said he wasn't allowed to.

A further and important ordeal for Polly to overcome was the limitations placed on her sexual relationships in the aftermath of unsuccessful gender reassignment 
surgery (and again Polly felt 'guilt'). A related 'ordeal' was Polly's need to 'pass' and have sexual allure as a woman:

We joined a swinging club as well. Met a couple and we went out a couple of times...well, it was just what I was going through, you know. It was part of what I was going through... was I being accepted as Polly ... I proved it, yes [I was].

Polly emphasised the importance of gendered clothing and other signifiers (hair) in the context of being able to 'pass'. She reflected on how she preferred to be addressed and the importance of using the correct terminology:

The thing is each time I'm going to meet somebody new you go a bit on the defensive. You're listening to every word they say, whether they might just mess up and say just refer to you as he or sir or something like that. That's why it's so important to say to the person 'How would you like me to address you'? If I said Poll, Polly, then you keep to that because it saves any of those little trip ups.

This represented a further aspect of the ordeal (the desire to pass), which is the need to be accepted by others and to be recognised as female, rather than trans. Polly articulated this in relation to social work, and emphasised this point in the excerpt below as being a woman for Polly involved both identification and ascription:

I'm female... So why should we have a label if I've had gender reassignment, or I haven't had gender reassignment surgery, but I am a female... why should I admit to being anything else but female? I had my name changed by deed poll in 1966 and legally once you've informed a health professional - a social worker, or a nurse or a doctor, anybody - the way you wish to be addressed, in the gender you wish to be addressed in, legally you are then changed to that gender.

In the penultimate stage of the quest, Polly still had to navigate 'A hostile terrain' (Booker, 2004: 83) and typically, transgender migrants can feel out of place in the 'new country' and that they do not belong (Ekins and King, 2006). Therefore, there was a demand for legal forms of recognition as a counter to the ordeals presented above.

\section{The goal}

The final stage of the quest is the 'goal', often when the central character finds a new home in a different location. For Polly, through her gender migration journey, self-acceptance and a sense of belonging in the new location represented the goal:

From the moment the hero learns of this prize, the need to set out on the long and hazardous journey to reach it becomes the most important thing ... the story remains unresolved until the objective has been finally, triumphantly secured (Booker, 2004: 69). 
Polly summarises her experiences thus:

[I have] gone through shit and come up smelling of roses [laughs]. It sounds jovial, flippant, but no ... I wouldn't want to go through it again ... In myself, I'm completely at ease with who I am.

Polly's journey was arduous, but she achieved her life-renewing goal and finally arrived 'home'. 'Countless transgender migrant autobiographies tell of exile in the 'wrong' gender role, of dreaming of being home in the 'right' one, of finally arriving home where one belongs' (Ekins and King, 2006: 44-45).

\section{Discussion and conclusion}

As highlighted above, structural narrative analysis is not unproblematic (Ahmed, 2013; Denzin, 1989, Minh-Ha, 1989), since it derives from Western conventions of storytelling. We are transparent in how we analysed Polly's narrative and how we have gained knowledge from it, and accept that the structure of a narrative is not 'given' or entirely external from the person who structures it. We appreciate that there are other forms of storytelling, which do not privilege Western narrative forms, but importantly, we acknowledge that we, Polly, and her narrative are situated within Western social, cultural, temporal and spatial contexts. Therefore, we are shaped by such Western narrative protocols and contexts, as is Polly, and the cultural resources she is able to draw upon to tell the story of her life and experiences of transgender simultaneously reflect and reproduce these contexts, as does our analysis. In this way, our contribution centres on how using a single case for analysis illuminates the unique biographies of individuals, while simultaneously reflecting and (re)constructing the context in which their narratives are produced. Polly felt that her lengthy and tortuous story of gender transitioning was typical, but not well understood by the social work profession. She offered a means to address this as the requirement to include awareness-raising in prequalifying training programmes (something which Polly was involved in at the point of interview).

Clearly, living as Polly presented ordeals and obstacles which she had to endure to reach her goal. How Polly presents the call, the journey and eventual goal, illuminates the material, social and cultural circumstances of her life, and gives insight to her situated experiences of transgender. This is particularly cogent for social work as trans people are relatively invisible as service users and their life experiences require a more informed understanding (Rogers, 2013, 2016). As such, a narrative approach can help to identify the barriers and enablers to service provision (Rogers, 2016). Indeed, as noted above, studies of trans subjectivity suggest that social workers can gain insight into trans experience and gender transitioning through stories (Rogers, 2013). These narratives can be understood in terms of rejection as being 'different', of guilt and shame, of relationship conflict and family dysfunction. These are not new concepts in the activity of social work, but ones 
which are not often heard from a trans perspective and therefore useful in terms of destabilising fixed notions of social category and experience. Thus, viewing narrative as a form of biographical work has value in offering previously hidden perspectives. Indeed, using structural analysis to understand Polly's biography has value in the process of identifying needs, risks and vulnerabilities as well as strengths, solutions and sources of support. As such, narrative facilitates an understanding of the micro-, meso- and macrolevels of influence in a trans person's life, and narratives illuminate how these levels overlap, disconnect, and how they shape agency and vulnerability at particular times in particular contexts. This approach emphasises micro-interactions and, consequently, encourages relationship-based social work (Ruch et al., 2010). This helps to move away from the technical, overly bureaucratic approach that has come to dominate contemporary practice (Featherstone et al., 2014).

Through her narrative Polly examines her life (Ricouer, 1984) and temporally organises disparate events, relating these to the lifecourse stages and contexts in which they occurred. The value of emplotment to social work not only lies in the ways in which people (like Polly) use plot to describe their lifecourse, experiences and relationships, but this practice extends into other forms of representation (for instance, in the production of social work case records and reports) (Baldwin, 2013). In this way, narrative practice structures how knowledge and actions are organised and presented in the recursive process of social work. Ultimately, the life-renewing goal (Booker, 2004) for Polly was achieving selfacceptance: this also represents the end point of plot movement (Bakhtin, 1981) and the reason she tells her story. The meaning and importance of acceptance should not be under-estimated in social work as Polly (along with others in the original study) suggests that by offering a personal narrative there was an implied request for some acknowledgement of their difficult journey, and also a need for recognition and validation. Furthermore, 'narrative social work' is consistent with the core values and principles of the profession in terms of encouraging inclusive practice which treats each person as a whole and as unique (Baldwin, 2013). Moreover, narrative inquiry can assist practice which integrates trans people's needs and desires (for example, in relation to the use of appropriate terminology and pronouns). This does not require considerable resources or a deviation from everyday tasks; it demands a reflexive form of practice which recognises and respects difference and diversity within the limits of existing social structures, institutions and inequalities.

Finally, an ethic which is central to these activities is professional integrity (BASW, 2012) and this can be achieved through narrative inquiry to facilitate a more sophisticated understanding of the lived experience of people who are marginalised (Rogers, 2016). Further, knowledge gained from an individual's unique, situated biography has the potential to inform social work interventions in order to contextualise trans people's past and present experiences against a backdrop of systemic and structural exclusion. In this way, the use of narrative helps to reflect the core social work values of human rights and social justice (BASW, 2012). 


\section{Declaration of conflicting interests}

The author(s) declared no potential conflicts of interest with respect to the research, authorship, and/or publication of this article.

\section{Funding}

The author(s) received no financial support for the research, authorship, and/or publication of this article.

\section{Notes}

1. Trans/transgender refers to a gender identity which is different to that which was ascribed at birth.

2. See for example Labov and Waletesky (1967); Goffman (1975); Riessman (1993); Doucet and Mauthner (2008); Ahmed (2013; 2015).

3. This denotes the beginning in Aristotle's definition.

4. This can be understood as the middle of the story.

5. This denotes the final stage.

6. We are aware that there are alternative trans auto/biographical stories, for example, oscillating stories, negating stories and transcending stories (see Ekins and King, 2006).

7. Cisgender refers to a person's gender identity which is the same as that which was ascribed at birth.

8. Meccano is a model construction system enabling the building of working models and mechanical devices.

\section{References}

Ahmed A (2013) Structural narrative analysis: Understanding experiences of lifestyle migration through two plot typologies. Qualitative Inquiry 19(3): 232-243.

Ahmed A (2015) Retiring to Spain: Womens' Narratives of Nostalgia, Belonging and Community. Bristol: Policy Press.

Bakhtin MM (1981) Forms of Time and of the Chronotope in the Novel. In: Holquist R (ed.) (2006) The Dialogic Imagination: Four Essays. Sixteenth Paperback Printing. Austin: University of Texas Press, pp. 84-258.

Baldwin C (2013) Narrative Social Work: Theory and Application. Bristol: Policy Press.

BASW (2012) The Code of Ethics for Social Work: Statement of Principles. Available at: http://cdn.basw.co.uk/upload/basw_112315-7.pdf (accessed 4 May 2016).

Benson M (2011) The British in rural France: Lifestyle migration and the ongoing quest for a better way of life. Manchester: Manchester University Press.

Booker C (2004) The Seven Basic Plots: Why we tell stories. New York: Continuum.

Burr V (1995) An introduction to Social Construction. London, Routledge.

Czarniawska B (2004) Narratives in Social Science Research. London: Sage.

Day Sclater S (1998) Nina's story: An exploration into the construction and transformation of subjectivities in narrative accounting. Auto/Biography $1 \& 2: 67-77$.

Denzin NK (1989) Interpretive biography. In: Qualitative Research Methods. Series 17. Newbury Park, CA: Sage.

Doucet A and Mauthner NS (2008) What can be known and how? Narrated subjects and the listening guide. Qualitative Social Research 8: 399-409.

Ekins R and King D (2006) The Transgender Phenomenon. London: Sage. 
Featherstone B, White S and Morriss K (2014) Re-Imagining child Protection: Towards Humane Social Work with Families. Bristol: Policy Press.

Gergen KJ (1999) An Invitation to Social Construction. London: Sage.

Goffman E (1975) Frame Analysis: An essay on the organisation of Experience. Harmondsworth: Penguin.

Gubrium JF and Holstein JA (1998) Narrative practice and the coherence of personal stories. The Sociological Quarterly 39: 163-187.

Gubrium JF and Holstein JA (2009) Analyzing Narrative Reality. Thousand Oaks: Sage.

Josselson T (2007) The ethical attitude in narrative research: Principles and practicalities. In: Helm $\mathbf{J}$ (ed.) Essays on the Verbal and Visual Arts. Seattle: American Ethnological Society, pp. 12-44.

Labov W and Waletesky J (1967) Narrative analysis: oral versions of personal experience. In: Helm J (ed.) Essays on the Verbal and Visual Arts. Seattle: American Ethnological Society, pp. 12-44.

Mills CW (1940) Situated actions and vocabularies of motive. American Sociological Review 5(6): 439-452.

Minh-Ha T (1989) Woman, Native, Other: Writing Postcoloniality and Feminism. Indianapolis, IN: Indiana University Press.

Nordmarken S (2014) Becoming ever more monstrous: Feeling transgender in-betweenness. Qualitative Inquiry 20(1): 37-50.

Polkinghorne DE (1988) Narrative Knowing and the Human Sciences. Albany: State University of New York Press.

Ricouer P (1984) Time and Narrative, Vol. 1. Chicago: Chicago University Press.

Ricouer P (1985) Time and Narrative, Vol. 2. Chicago: Chicago University Press.

Ricouer P (1988) Time and Narrative, Vol. 3. Chicago: Chicago University Press.

Riessman CK (1993) Narrative Analysis (Qualitative Research Methods). Thousand Oaks: CA: Sage.

Riessman CK (2000) Analysis of Personal Narratives. In: Denzin N and Lincoln Y (eds) Handbook of Qualitative Research. Thousand Oaks, CA: Sage, pp. 695-710.

Riessman CK (2003) Performing identities in illness narrative: masculinity and multiple sclerosis. Qualitative Research 3: 5-33.

Riessman CK (2008) Narrative Methods for the Human Sciences. London: Sage.

Rogers M (2013) TransForming practice: Understanding trans people's experience of domestic abuse and social care agencies. PhD Thesis, University of Sheffield, UK.

Rogers M (2016) Breaking down barriers: Exploring the potential for social care practice with trans survivors of domestic abuse. Health and Social Care in the Community 2(1): 68-76.

Ruch G, Turney D and Ward A (eds) (2010) Relationship-based Social Work. London: Jessica Kingsley Publishers.

Saleebey D (2013) Strengths Perspective in Social Work Practice, 6th ed. Boston: Pearson. Spradley JP (1979) The Ethnographic Interview. New York: Holt, Rinehart and Winston.

Stanley L and Temple B (2008) Narrative methodologies: Subjects, silences, re-readings and analyses. Qualitative Research 8(3): 275-281.

Temple B (2008) Investigating language and Identity in cross-language narratives. Migrations and Identities 1(1): 1-18. 